Original Paper

\title{
Evaluation of Micro Grid including Power Storage Device
}

\author{
Takao ShinjI*1, Tetsuo YAmakAmi*1, Akito MoriYama*1, Atushi AKISAWA*1, \\ Takao KASHIWAGI*2, Goro FUJiTA*3, and Masayoshi MATSUBARA*3 \\ (Received January 7, 2008)
}

\author{
電力貯蔵設備を含んだマイクログリッドの評価 \\ 進士誉夫*1，山上哲雄 ${ }^{* 1}$ ，森山顕仁 ${ }^{* 1}$ ，秋澤 淳*1，柏木孝夫*2，藤田吾郎*3，松原正芳*3
}

\begin{abstract}
Renewable energies such as wind power or photovoltaic energy are getting attentions for view points of energy conservation and environmental issue. However, fluctuation of output power of renewable energies may cause excess variation of voltage or frequency of the grid. Increase of the amount of renewable energies would violate the quality of the grid. The micro grid in which dispersed energies compensate the variation from the renewable energies can expand the installation limit of the renewable energies by maintaining the quality of the interconnected grid.

In this paper, evaluation of ratio of gas turbines, gas turbines and batteries is discussed from the point of power flow stability of the grid, efficiency and economy. Gas turbines have quicker response and lower efficiency, whereas gas engines have slower response and higher efficiency. Best ratio is discussed for higher efficiency while fluctuation of output power of the micro grid is kept in a small amount. Additionally, introducing batteries is discussed to introduce more gas engines he point of power flow stability of the grid, efficiency and economy.
\end{abstract}

\section{Key Words}

Dispersed power source, Micro grid, Renewable energy, Wind power, Power flow fluctuation,

Power storage device

\section{1. はじめに}

温室効果ガスによる地球温暖化を回避するために京都議定 書目標達成計画をはじめ国家レベルでの取り組みが行われて いる。風力発電, バイオマス発電, 太陽光発電に代表される 再生可能エネルギーは環境性には優れているものの, 電力系 統に与える影響が無視できず，導入に制限がかかる場合があ る。その導入枠拡大の方策のひとつとして近年マイクログ リッドが注目されている。

配電系統に打ける分散電源の普及にあたっては, 電力流通 設備を含めた形成のあり方から，電源構成，周波数や電圧と いった電力品質の確保の問題まで, 多くの課題が揭げられて いる。とりわけ, 電力品質の確保は分散電源普及のポイント であり，これまで多くの研究が行われてきている。例えば，分

\footnotetext{
* 1 Tokyo University of Agriculture \& Technology 2-24-16 Nakamachi, Koganei-shi, Tokyo 184-8588, Japan

* 2 Tokyo Institute of Technology

2-12-1 Ohokayama, Meguro-ku, Tokyo 152-8550, Japan

* 3 Shibaura Institute of Technology 3-7-5, Toyosu, Koto-ku, Tokyo 135-8548, Japan
}

散電源普及時には逆潮流の発生や不平衡運転, そして調相運 転の考え方について考察をする必要があり, 電圧変動という

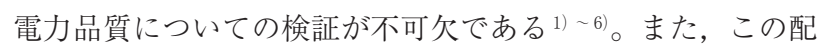
電系統が，マイクログリッドのように閉じられた形態となっ た場合, 系統連系の有無に応じた需給バランスの調整も大き な課題となる。具体的には, この配電系統が大規模な電力系 統に隣接している場合, 系統連系が可能であり, 交流連系で あれば周波数の維持は大規模電力系統が責務を負うことから， 連系線の潮流制御を行うことで配電系統内の需給制御を達成 できる。潮流制御の一方, 離島のように単独系統の場合には, 配電系統の需給バランス維持は自らの責務によるほかなく, 需給アンバランスは周波数変動に直接影響を及ぼす。このほ か, 連系運転から単独運転への移行時や, その逆の過渡状態

\footnotetext{
* 1 東京農工大学大学院生物システム応用科学府 干 184-8588 東京都小金井市中町 2-24-16

* 2 東京工業大学統合研究院大学院理工学研究科 ₹ 152-8550 東京都目黒区大岡山 2-12-1

* 3 芝浦工業大学工学部電気情報系電気工学科 † 135-8548 東京都江東区豊洲 3-7-5
} 
についても，検討の余地がある7)。2005 年には愛知万博にお いて, 新エネルギー等地域集中実証研究プロジェクトが実施 され，複数分散電源による電力供給が実施された。本実証試 験の焦点の 1 つ, 異なる運転特性を持つ分散型電源を組み 合わせてどのように需給バランスを維持するかであり，太陽 光発電は出力变動が激しいことから，NaS電池を用いて需給 調整が行われた ${ }^{8)}$ 。

このように電力貯蔵設備を併用することは, 分散電源の普 及促進に大きく貢献するが，その必要容量や制御特性につい ては，今後の課題となっている。そして，デバイスの組み合 わせにより，マイクログリッドの最適な電源構成のあり方を 考察する必要がある。

このような研究背景に鑑み，筆者らは配電系統の需給制御 モデルを構築し，マイクログリッドにおける好ましい需給制 御のあり方について検討を行ってきた ${ }^{9)}$ 。具体的には可変出力 であるガスタービン発電機, 不規則な出力の風力発電機, 固 定出力の燃料電池から構成される小規模系統を構築し，ガス タービン発電機の運転効率低下ならびに風力発電機の導入限 界についての定量的考察を行った。

この研究により, 風力発電による電気出力の変動をマイク ログリッド内に設置されたガスタービンの出力を変動させる ことにより，マイクログリッドから系統に及ぼす出力変動(本 論文では連系線潮流の標準偏差 Ptie をマイクログリッドの系 統に与える影響のひとつの指標としている）を抑制すること ができることが判明した。しかしながら，マイクログリッド から系統に及ぼす出力変動を抑制する装置としてはガスター ビンよりも制御応答性は悪いが発電効率の高いガスエンジン や省エネルギー効果はないものの制御応答性の高速な蓄電池 が考えられる。

そこで本報告では，必要とされる設備容量および運用手法 について考察を行ない, 電力貯蔵設備の有用性について検証 を行った。

\section{2. モデルの概要と前提条件}

2.1 マイクログリッド

マイクログリッドとはFig. 1に示すようなシステムであり， ある系統に風力発電，ガスタービン，燃料電池などの発電設 備を組み合わせ，系統と一点で連系しているシステムを示す。

今回の考察に用いたモデルは Fig. 2 に示すモデル 10) 15) で あり, 風力発電 $(\mathrm{WF})$ の変動と負荷の変動によって生ずる連 系線潮流の変動をガスタービン (以下 $\mathrm{GT}$ ), ガスエンジン (GE), 蓄電池 $(\mathrm{BT})$ に対して連系線潮流の設定值に対する偏 差をフィードバックし，連系線潮流の設定值からの偏差を少 なくするように各発電設備, BTの容量に応じて発電出力を制 御している。今回の考察に用いたモデルは Fig. 2 に示すモデ ル 10) -15) であり, 風力発電 (WF) の変動と負荷の変動によっ て連系線潮流に変動が発生する。これをガスタービン（以下 $\mathrm{GT})$, ガスエンジン (GE), 蓄電池（BT の出力を制御するこ とにより抑制している。なお, 連系線潮流は, 設定值に対す る偏差をゼロと目標にすることも可能であるが，ここでは設

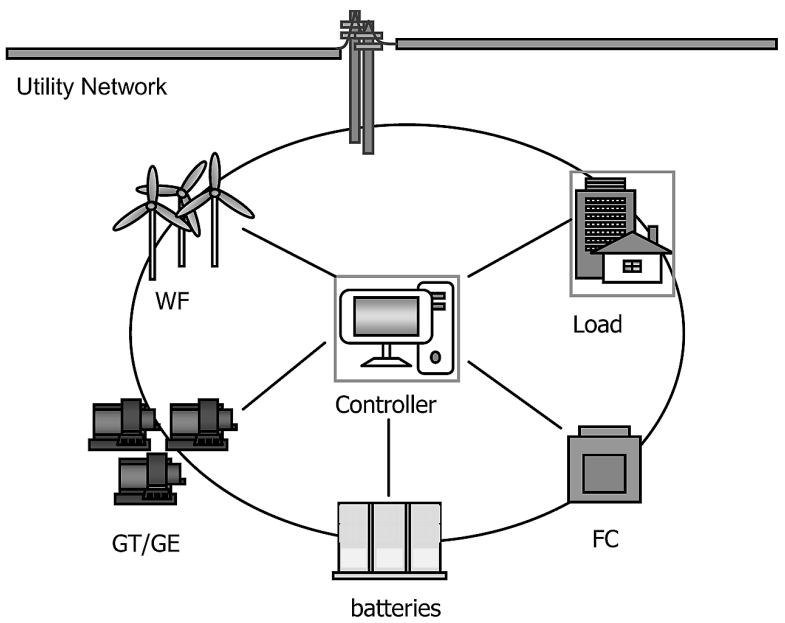

Fig. 1 Concept of micro grid

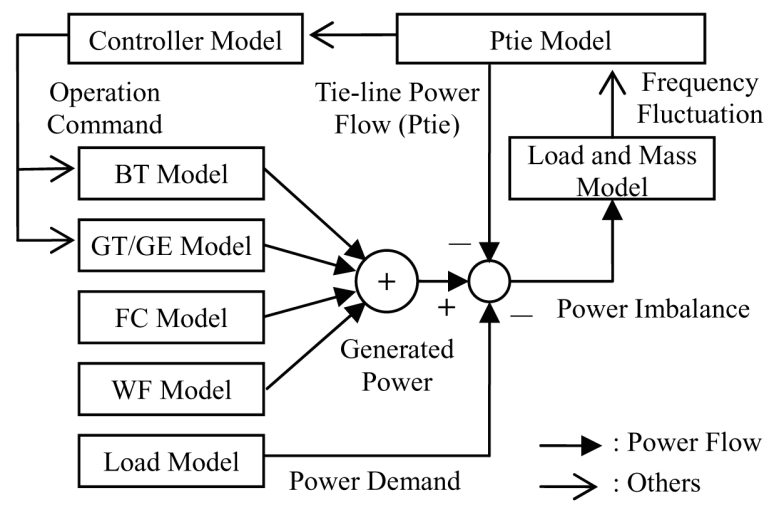

Fig. 2 Micro grid block diagram

定值をゼロとしているため, 連系線潮流変動そのものを抑制 することが目標となる。

本稿で用いる標準的な構成を Table 1 に示す。風力発電 (WF) はここでは平均出力を導入量として位置づけている。ま た燃料電池 (FC) は固定出力である。詳しくは文献9)を参照 されたい。

GEは発電効率がよいが, 負荷追従速度がGT と比較して低 い。またBTはGTよりも応答速度が速いのが特徵である。こ れにより，4000 [S] のシミュレーションを行った結果の一例 がFig.3である(GT51MW，GE49MW，FC10MW，WF16MW)。 省エネルギー性の観点からはGEをできるだけ多く使いたい が，系統に対する影響を抑えるには一部GTを使用しなければ ならない。このような条件の下，省エネルギー性，経済性の 観点から最適な電源構成を考察した。

Table 1 Standard configuration of micro grid

\begin{tabular}{|c|c|c|c|}
\hline Generators & Capacity & $\begin{array}{c}\text { Load } \\
\text { following } \\
\text { speed }\end{array}$ & Comments \\
\hline GT & \multirow{2}{*}{$100 \mathrm{MW}$} & $8.3 \% / \mathrm{min}$. & \multirow{2}{*}{$\begin{array}{c}\text { Output range } \\
50 \sim 100 \%\end{array}$} \\
\hline $\mathrm{GE}$ & & $4.15 \% / \mathrm{min}$. & \\
\hline BT & $0 \mathrm{MW} \sim$ & $6.7 \% / \mathrm{s}$ & Capacity varies \\
\hline WF & $0 \mathrm{MW} \sim$ & - & Capacity varies \\
\hline $\mathrm{FC}$ & $10 \mathrm{MW}$ & - & Constant \\
\hline
\end{tabular}




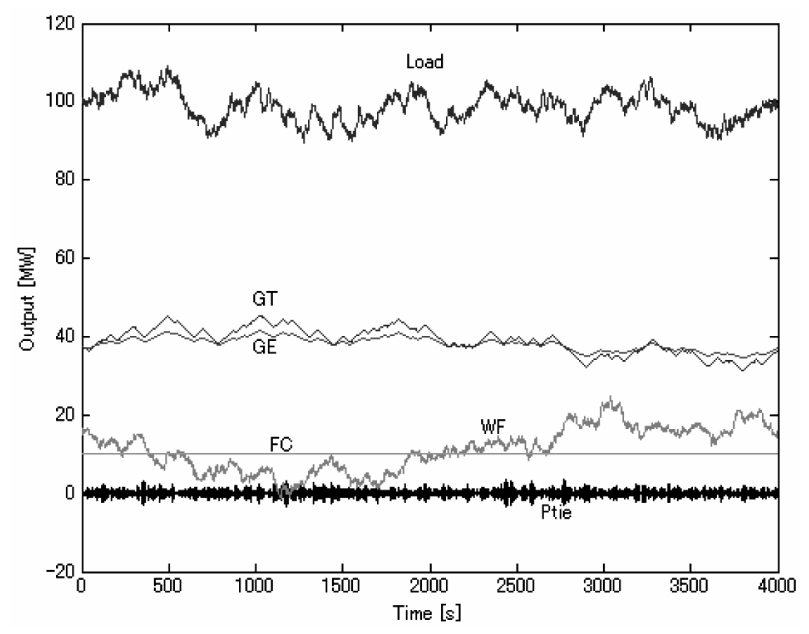

Fig. 3 Sample of simulation output

Table 2 Efficiency of generators (\%)

\begin{tabular}{l|c|c|c}
\hline Efficiency index & GT & GE & FC \\
\hline Electric output & 25 & 35 & 40 \\
\hline Thermal recovery & 40 & 30 & 40 \\
\hline Overall efficiency & 65 & 65 & 80 \\
\hline Overall efficiency in PURPA $^{16)}$ & 45 & 50 & 60 \\
\hline
\end{tabular}

\section{2 効率の考察}

Table 2は, 分散型電源の一般的な効率の比較について示し ている。マイクログリッド全体の省エネルギー性を考慮する とGTより発電効率の高い GEの導入が有利である。しかしな がら，GEはGTに比較して制御応答性が悪いので，連系線潮 流変動を抑制するには不利である。

\section{3. ガスエンジンがマイクログリッド挙動に与える影響}

3.1 GE 導入による連系線潮流の変化

Fig. 4はGE導入による連系線潮流の変化を示している。GT をGEに置き換えて導入していった場合，GEの割合が大きく なるほど制御応答性が悪いため, Fig. 4に示すように連系線潮 流変動の標準偏差が大きくなる。

同じ大きさの負荷変動と発電設備の変動の系統の周波数に 与える影響が同じであることから，マイクログリッドが系統 連系している場合の連系線潮流の目標値のひとつとして, “負 荷変動と同程度の変動レベル”が考えられる。すなわち，ど の系統でも “負荷変動” は常に生じているものであり, 負荷 変動に風力発電の変動が加わり変動が大きくなっても, GTな

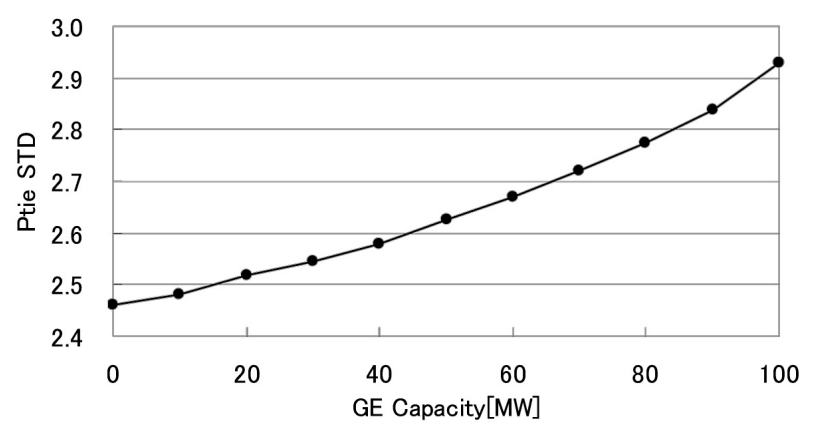

Fig. 4 Ptie STD by installation of GE

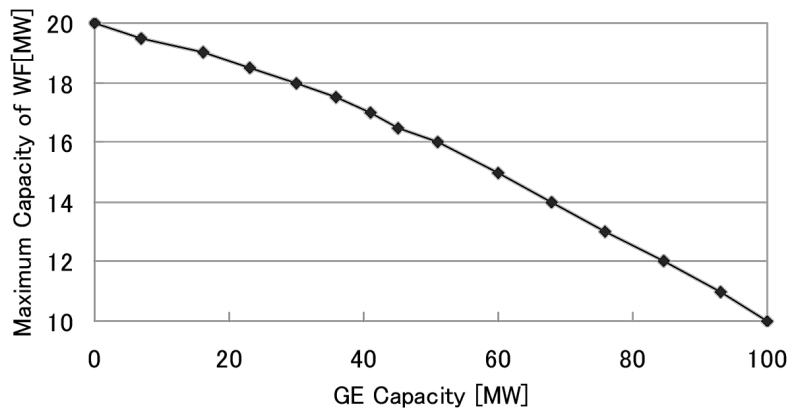

Fig. 5 Maximum WF installation by GE

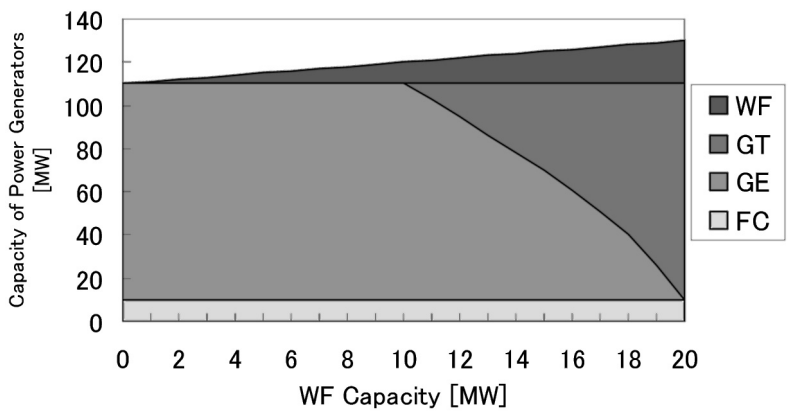

Fig. 6 Configuration of generators

どによりその変動を抑制してもとの負荷変動のみの場合の変 動レベルに戻すことができれば，風力発電の変動は抑制され ているという考え方である。この考えに基づき, 連系線潮流 変動の標準偏差 (図中ではPtieSTD と表示) がマイクログリッ ド全体の容量の $3 \%$ 以内をひとつの基準とする。3\%はひと つの目安であるが, 特定電気事業者の電力会社との受電点潮 流変動幅など他の類似例を参考として設定した。

ここで現状の上述の基準（連系線潮流変動の標準偏差が 3 \%以内）に基づいて，10MWの GTをGEに置き換える形で GE を導入した場合，連系線潮流の変動は大きくなる (Fig. 4)。風 力発電の導入時に連系線潮流変動の標準偏差が $3 \%$ 越えない 範囲の最大の GE の導入量を Fig. 5 に示す。

連系線潮流変動の標準偏差が $3 \%$ 以内の基準の下では, WF が10MW（全体の容量の10\%）までであればGTすべてを GE に替えることができる（Fig. 6)。

この場合 GT のみの場合に比較して発電効率は最大 $15 \%$ 向 上する。

\section{4. 電力貯蔵装置による連系線潮流変動の改善}

4.1 BTの最適ゲインの考察

Fig. 7 より BTのゲイン（連系線潮流の偏差に対する出力減 の割合）は約 3 まではPtieの変動の改善が見られるが, それ 以上大きくしても, 改善は見られないことがわかる。今後, BT のゲインの最適值を 3 と設定して，この值で考察を進める。

\section{2 風力発電設備導入可能量の考察}

Fig. 8は, WF導入による連系線潮流変化である。連系線潮 流の標準偏差の上限值 $3 \%$ を基準とするとその導入限界はGT

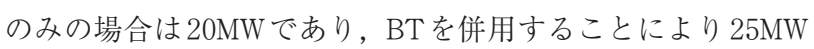




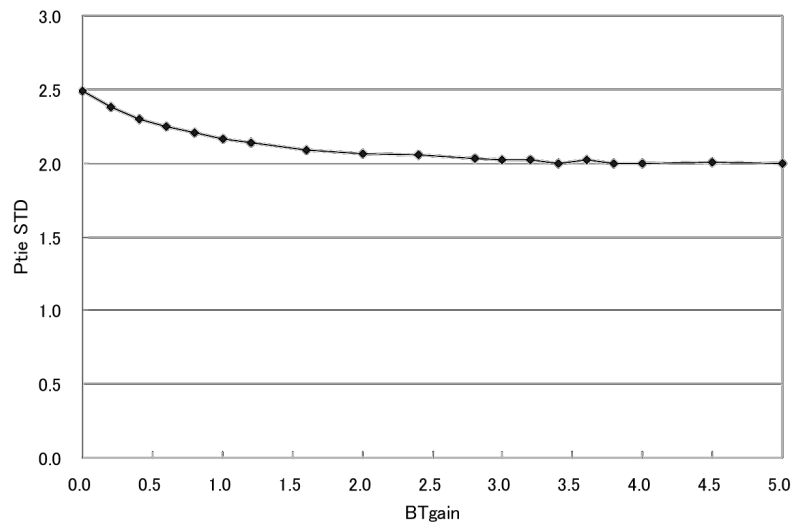

Fig. 7 Ptie STD by BTgain

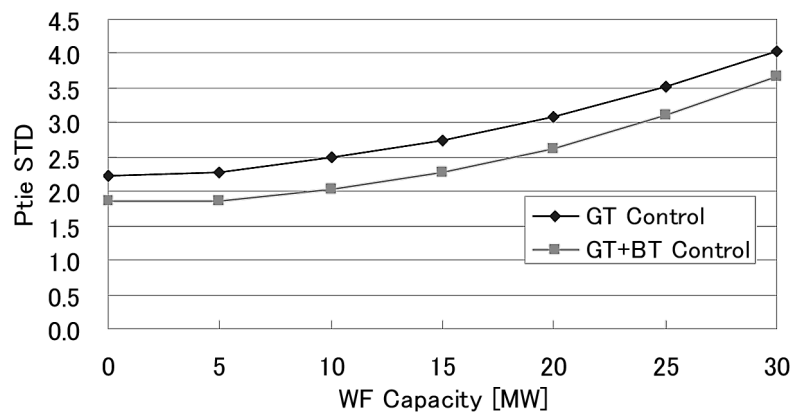

Fig. 8 Ptie STD by WF

まで拡大できる(WF の容量は 7.5MW として試算)。

WFを導入した場合に, 連系線潮流の変動を標準偏差 $3 \%$ 以 内に抑制するためには，GTをGEに置き換えて導入しなけれ ばいけない。そのような置き換えを行ったことによるマイク ログリッド全体の総合発電効率は次式であらわされる。

$$
\begin{aligned}
& \eta=\frac{W}{E_{G T}+E_{G E}+E_{F C}} \\
& \eta: \text { 総合発電効率 } \\
& W: \text { システム全体の出力 } \\
& E_{G T}: \mathrm{GT} \text { の投入一次エネルギー } \\
& E_{G E}: \mathrm{GE} \text { へ投入一次エネルギー } \\
& E_{F C}: \mathrm{FC} へ の \text { 投入一次エネルギー }
\end{aligned}
$$

このときの変化を Fig. 9 に示す。WF の容量 10MW までは GEのみで対応できるが, それを超えると GT の導入が必要 となり，総合発電効率は低下する。

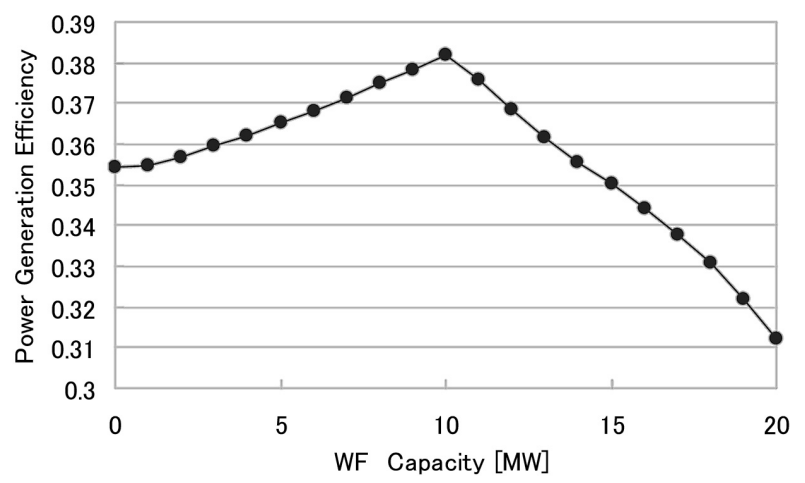

Fig. 9 Total efficiency by installation of WF

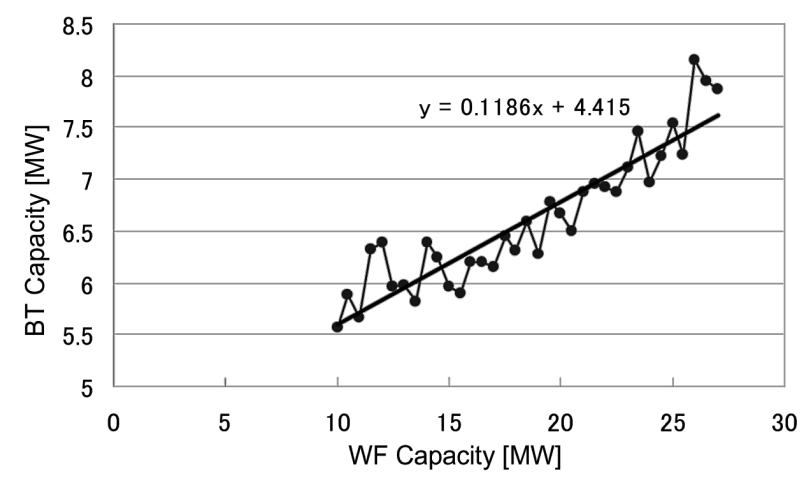

Fig. 10 BT installation by WF installation

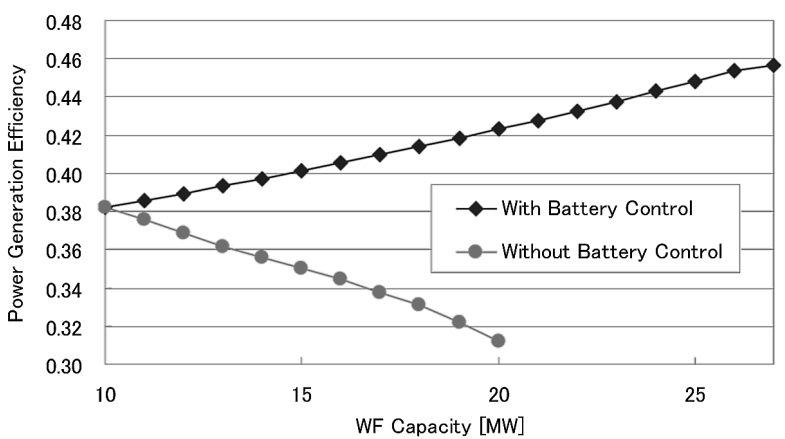

Fig. 11 Total efficiency by WF installation

\subsection{BT の容量の考察}

今回のシミュレーションではBTの上下限值は設定している が，その範囲内で運用することができており，さらにBTの容 量を小さくする余地がある。そのような考え方でシミュレー ションの結果, BTの出力変動の最大振幅によって BTの容量 を決定すると, WFの導入量に応じてFig. 10のようになる。図 に示すように直線近似できることがわかる。

Fig. 11 はBT を導入することにより, マイクログリッド全 体の発電効率を低下させることなく, WFを導入することが可 能となることを示している。これはGTの導入量の増加を回避 できるのが理由である。

\section{5. 電力貯蔵装置導入の経済性評価}

最後にシステムの電源構成をコスト面で評価する。BT導入 時, WF導入量が多くなり, マイクログリッド全体の発電効率 も上昇することがわかるが, BTのイニシャルコスト, WFの イニシャルコストが増加する。そこで, WF導入量増加による 発電電力量の価值と, $\mathrm{BT}, \mathrm{WF}$ のイニシャルコスト増加との 関係を考察する。

$\mathrm{BT}$ なしの場合, 発電効率最大の WF $10 \mathrm{MW}$ 導入時の WF 導 入量を“WF1”とし, コスト比較対象を BT 導入時の WF 導入 量が10〜27MWの“WF2”とする。

$\mathrm{WF}$ 発電電力の価值の BT 有無での差を $P[$ 円/年 $]$ とすると 以下が得られる。

$P=(W F 2-W F 1)[\mathrm{MW}] \times 8760[\mathrm{~h}] \times 16.5[$ 円 $/ \mathrm{kWh}]$

電力単価 16.5 円 $/ \mathrm{kWh}$ は業務用電力の代表的な值からとっ た。 
本研究の WF 出力モデルは風況が比較的安定した $4000[\mathrm{~s}]$ でのシミュレーションであるが，年間を通しての考察では風 力発電の負荷率を一般的な值である $0.15 \sim 0.25$ と変化させ, それぞれの值での $P$ を求める。

$\mathrm{GE}$ 導入量は両者とも $100 \mathrm{MW} ， \mathrm{FC}$ 導入量も $10 \mathrm{MW}$ であるの で，Pと比較するコストは，WF イニシャルコストの差と BT イニシャルコストである。WF, BT のイニシャルコストはシ ミュレーションによりPtie が 3 \%を超えない最低の容量から イニシャルコストを求め, 法定耐用年数で割り，Pと比較す る。なお，本研究の WF, BT のイニシャルコストは 25 万円/ $\mathrm{kW} ， 10$ 万円 $/ \mathrm{kW}$ ，法定耐用年数は 17 年， 8 年と定める。

以上により負荷率 0.15 及び 0.25 の場合の WF の導入による マイクログリッド全体の発電効率も上昇とWFと BTイニシャ ルコストを経済的観点から評価した結果を Fig. 12, 13 に示

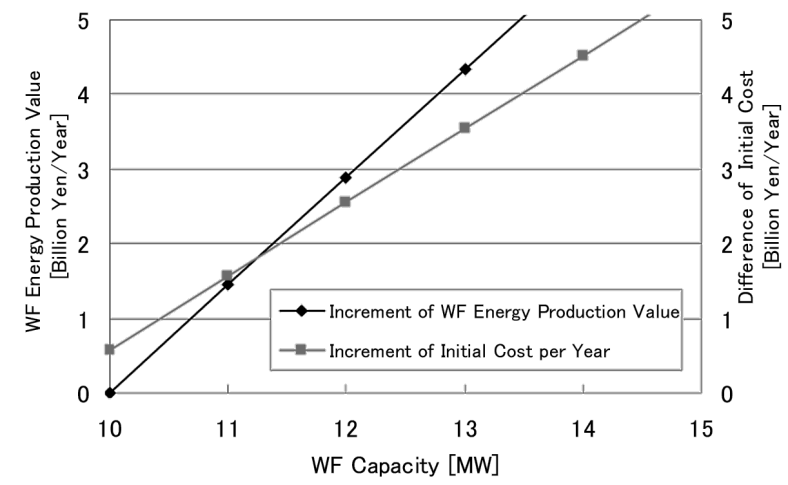

Fig. 12 Economical merit by installation of WF \&BT (Load factor 0.15$)$

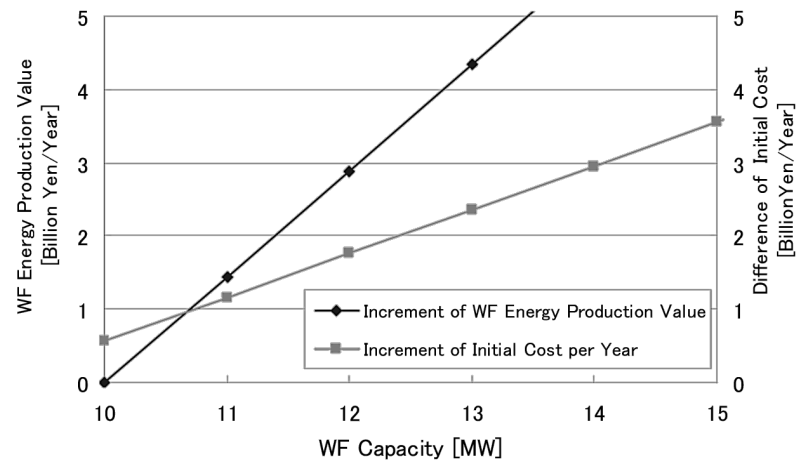

Fig. 13 Economical merit by installation of WF \&BT (Load factor 0.25 )

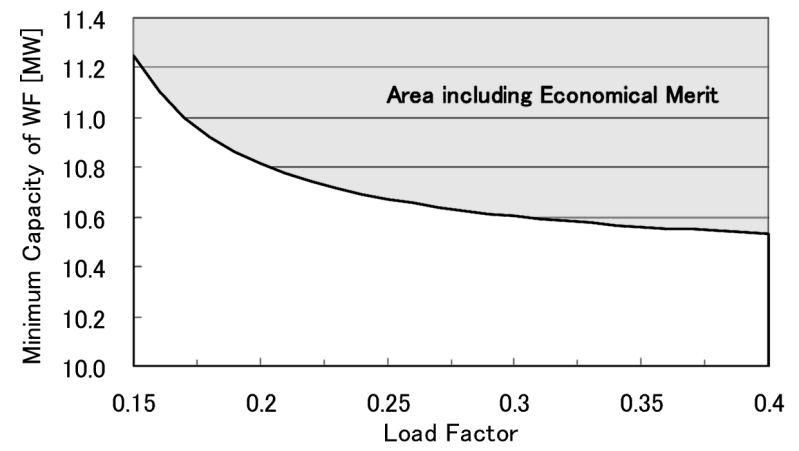

Fig. 14 Minimum WF installation for economical merit
す。負荷率 0.15 の場合, WFを $11.2 \mathrm{MW}$ 以上導入した場合にメ リットが出ることがわかる。Fig. 14 より, WF の負荷率も考 慮した結果, BT導入の際, 風力発電導入量が最低でも $10.4 \mathrm{MW}$ 以上必要となる。

\section{6. まとめ}

以下に本研究で得られた事項をまとめる。

(1) マイクログリッドに導入されたWFの出力変動によって生 じる連系線潮流の変動を 3 \%以内に抑制するには, WFの 容量がマイクログリッド全体の 10\%（10MW/100MW）以 内であればGEの出力制御により変動を抑制することが有 効であることが判明した。

(2) WF の容量がマイクログリッドの $10 \%$ を超えると，GEよ りも制御応答性のよいGTを導入しなければWFの出力変 動によって生じる連系線潮流の変動を 3 \%以内に抑制する ことができなくなる。しかし，GTは発電効率が低いので マイクログリッド全体の総合的な発電効率は低下してしま う。

（3）10\%を超えるWFの導入による出力変動の抑制には，制御 応答性のよい BT の導入が有効である。

(4) WF と BT のイニシャルコスト対ランニングメリットの比 較では WF 導入は 10.4MW 以上でないとメリットがない。

（5）今回の考察はWFの出力変化が比較的連続した場合の結果 であるが，無風状態から出力が急増する場合や，その逆に 急に無風状態になる場合を考察すると, 最大 $10 \mathrm{MW}$ 出力 変化が生じる可能性がある。このように大きな変動が生じ た場合には，GT，GEの追従速度特性に制約があるため, まれに今回示したような制御ができない可能性がある。し かし今回の評価では 4000 秒間での統計的な標準偏差で評 価しており，評価結果に大きな影響を生じないと考えられ る。

\section{文 献：References}

1) Ramirez, A., Semlyen, R., Iravani, IEEE Transactions on Power Delivery, 19(3),(2004)

2) 山本茂広, 角和芳, 西川榮一, 橋本武, 電気学会論文誌 $B$ (電力・エネルギー部門誌), 124(4),(2004)：Yamamoto, S., Sumi, K., Nishikawa, E., Hashimoto, T., IEEJ Transactions on Power and Energy, 124 (4),(2004)

3) Bhowmik, A., Maitra, S., Halpin, M., Schatz, J. E., IEEE, Transactions on Power Delivery, 18(2),(2003)

4) Oliva, R., Balda, J. C., IEEE, Transactions on Power Delivery, 18 (2),(2003)

5) Marei, M. I., El-Saadany, E. F., Salama, M. M. A., IEEE, Transactions on Power Delivery, 19 (3),(2004)

6）奥山賢治, 加藤丈佳, 吳力イ, 鈴置保雄, 舟橋俊久, 電気 学会論文誌 $\mathrm{B}$ (電力・エネルギー部門誌)，123(3),(2003)： Okuyama, K., Kato, T., Wu, K., Suzuoki, Y., Funabashi, T., IEEJ Transactions of Power and Energy, 123 (3),(2003)

7）辻隆男, 大山力, 熊野照久, 河野良之, 伊与田功, 電気学 
会論文誌B(電力・エネルギー部門誌)，124(3), 6(2004)： Tsuji, T., Oyama, T., Kumano, T., Kono, Y., Iyoda, I., IEEJ Transactions of Power and Energy, 124 (3),(2004)

8）中村公雄, 角田二郎, NTTファシリティーズジャーナ ル, 43, $253(2006-1)$ : Nakamura, K., Tsunoda, J., NTT Facilities Journal, 43, $253(2006-1)$

9）進士誉夫，関根剛史，秋澤淳，柏木孝夫，藤田吾郎，松原 正芳，電気学会電力，エネルギー部門誌 (B), 126 (1), (2006) : Shinji, T., Sekine, T., Akisawa, A., Kashiwagi, T., Fujita G., Matsubara, M., IEEJ Transactions of Power and Energy, $126(1),(2006)$

10) Kundur, P., Power System Stability and Control, (McGrawHill),(1994)

11) Wood, J., Wollenberg, B. F., Power Generation Operation and Control,(Wiley),(1996)

12）電力系統における常時及び緊急時の負荷周波数制御調査専 門委員会,「電力系統における常時及び緊急時の負荷周波 数制御」, 電気学会技術報告, No. 869,(2003)：Research Committee of Power System Load Frequency Control for
Normal and Emergency Operation, 'Power System Load Frequency Control for Normal and Emergency Operation, IEEJ Technical Report, No. 869,(2003)

13）道上勉, 大石孝穂, 電気学会論文誌, 120-B, 7 (2000)： Michigami, T., Oishi, T., IEE Japan, 120-B, 7 (2000)

14）新エネルギー・産業技術総合開発機構/電力中央研究所, 「風力発電電力系統安定化等調査」, NEDO-NP-0012： NEDO/CRIEPI, 'Research on Power System Stabilization of Wind Generation', NEDO-NP-0012

15）中村哲廣, 江崎公太, 柿沼絵美, 藤田吾郎, 山口剛史, 横 山隆一, 小柳薰, 舟橋俊久, 電力技術研究会研究資料, PSE-04-3 (2004)： Nakamura, A., Ezaki, K., Kakinuma, E., Fujita, G., Yamaguchi, T., Yokoyama, R., Koyanagi, K., Funabashi, T., The Papers of Technical Meeting on Power Systems Engineering, IEE of JAPAN, PSE-04-3(2004)

16）岡本洋三, 坂倉淳, 秋澤淳, 柏木孝夫, 日工ネ誌, 84 (10),(2005) : Okamoto, Y., Sakakura, A., Akisawa, A., Kashiwagi, T., J.Jpn. Inst. Energy, 84 (10),(2005) 